\title{
Study on the Virtual Image Design of "Post- Apocalyptic" Style Science Fiction
}

\author{
$\mathrm{Yu}$ Guo \\ Film-Video-Animation School \\ Sichuan Fine Arts Institute \\ Chongqing, China
}

\author{
Yanzheng Xie \\ Film-Video-Animation School \\ Sichuan Fine Arts Institute \\ Chongqing, China
}

\begin{abstract}
This article focuses on the analysis of "postapocalyptic" style in science fiction, outlining the evolution of this style and its features which has certain reference for the creation of this type of work.
\end{abstract}

Keywords-post-apocalyptic style; science fiction; virtual image design

\section{The Definition of "Post-Apocalyptic" Style}

The "Revelation" in Bible also known as "Apocalypse". It is the last chapter of "New Testament". It is said to be written by the disciple of Jesus John and it mainly is the warning to the future of the world, including the doomsday prophecies. "PostApocalypse" is mainly shows the destroyed world, survived people struggling to survive in the wilderness and wasteland, animals and people in order to adapt to the new environment occured different variations either from physical or psychologically. Twisted and deformed humanity and the pressure to survive in wasteland are the charm of "postapocalyptic" style.

"Post-apocalyptic" style is a branch of science fiction video game, which exists as "future tense", emphasize the era in which people live are affected by major wars, plagues, disasters and shrouded in shadow of fear and desolation. Backgrounds are related to the fear of people's living at the time. Such like 70s in "Mad Max", the panic caused by oil, 80 s in "Blade Runner" the panic caused by computers and 90s in "The Matrix", the panic caused by network. Twenty-first century, we thought it would the panic caused by virus, genetic manipulation / biology. This style works try to convey a dark, desolate, fear theme.

Science fiction film, just as the name implies, that is "science and fiction film", is ""the feature film with science and fiction as it content, its basic characteristic is based on the current scientific principles and scientific achievements, to make fantasy description for the future world or the distant past scenarios". Sci-fi film always inseparable with horror and fear components, it uses human fear of the unknown and curiosity to attract viewers. Such as "Alien", "Independence Day" uses the fear to the aliens; "Doomsday", "Tokyo sank" and so on use the fear to universe and the nature. To be different with fear of the unknown in general science fiction type, "post-apocalyptic" type style is to use people's fear to current known things. The most common is the fear to nuclear weapons and viruses, and it must happened after the world suffered enough a disaster which is enough to change people's living conditions, in short, is the "end of the world."

\section{The PRESENT SituAtion OF THE DEVELOPMENT OF CONTEMPORARY "POST-APOCALYPTIC" STYLE}

\section{A. Origin of "Post-Apocalyptic" Style}

As early as the 1960s during the Cold War, Stanley Kubrick's black humor science fiction film "Dr. Strangelove" (or: "How I Learned to Stop Worrying and Love the Bomb") shows the drama of world destruction in a joking way, in the music sound of "we will soon meet again",blow the earth upside down floridly. The emergence of such a film undoubtedly injected new blood for the film genre at that time, so a large number films and television works with the "postapocalyptic" spirit have sprung up.

\section{B. The Development of "Post-Apocalyptic" Style and the Performance in Films and TV Works}

1) When the Earth is no longer belong to human being: The most direct way to destroy the world is appeared a group of biotic or abiotic mutants who swept out human beings like rubbish. Our filmmakers have always been willing to create such mighty badass, and the human world will be decimated by them. But they will be eventually beaten down by our human hero in front of the screen. Although having the similar routine, they such as "Reign of Fire" were able to show the sinister dark end of the world delicately and lifelike. When Christian Bale facing the huge dragon on the devastated ruins in London, the survivor's survival and resistance will were enough stirring.

Speak of mutant theme, how can we missed zombies. Ever since George Romero turned his fear of communism into the Living Dead trilogy, the countless zombies have always been one of the biggest nightmares on the screen. Although later there was the "28 Days Later" which described a desolate London accurate in place; also the "I Am Legend" portrayed the destroyed New York Majestically. But I think the one with the most eschatological flavor is the supermarket was surrounded by thousands of living dead in "Dawn of the Dead". Few human beings trapped in this island, desperate to spend the last time. 
In addition to creature, machine is a role that often destroys the world. From the Skynet in "Terminator", to the powerful machine civilization in "The Matrix", they all turned human world into ruins, but the end of the world that they created was far not attractive compare with themselves.

2) The ultimate nightmare of 20th century: nuclear war: In the latter half of 20th century, nuclear war just like a real nightmare, tormented the whole world in every second. At that time mankind is so close to destruction. So use nuclear war to create eschatology, therefore, logically became the things which make the filmmakers take pleasure in, and the doomsday movies which related with nuclear war are numerous.

"After the Holocaust" was a TV movie filmed in 1983. It used a documentary approach, detailed portrayed a abnormal lifelike picture of nuclear war. Under the cloud of nuclear war, ordinary people are so tiny; in front of the most powerful force, human beings are so fragile; in the tragic end of the world, people's struggle are so weak ... Every minute of the films are realistic almost cruel. When the hero who severely tortured by nuclear radiation passing through thousands crowded wounded people, wilderness which dead of vitality only left a variety of creature's remains, for the whole world turned into endless ruins. Nuclear war, this ultimate disaster of human beings was showed naked in front of everyone.

3) Eschatological freehand and realism: Eschatology could just be a concept, a background and a touch, but also it could be a real that deep to the bone.

Let us start from the dark cold near future of "Blade Runner" , in this 2020, even though the world have not been destroyed, but the people's heart has already become desolate ruins in the airless technology industry, decadent and loneliness. Here, humans and artificial people again to maintain their existence by killing each other and death. That poignant picture is not the end of the world but even darker and more desperate. When Bruce Willis of "12 Monkeys" climbed from the underground up on the wasted land, he saw a silent decay and desolation, a black bear behind him scornfully looked down the only human on the ground. This accurate model description of"12 Monkeys" was undoubtedly the classics of films. But in this book of Terry Gilliam, eschatology was just a gorgeous background. Here, history and science \&technology, system and nature, humanity and ideology formed a group of circulation in the madness and confusion, philosophical paradox never with an answer.

And compare with the freehand of the above two films, the eschatology of "Children of Men" was as realism as if everything happened in front of you. When all humans lost reproductive capacity, tomorrow has become a concept cannot be reproduced in aging day after day, the inevitable arrival of tomorrow has become one of the most poisonous curse. And when the long lend through the last time of mankind, every inch of the ruins, every death was so fingertips. And despair was like air in here, which already infiltrated every inch of land in this world and every human cell...

\section{The Design Elements And BAsic Methods OF "Post-APOCALYPTIC" STYLE}

\section{A. Element 1 : Ruins}

The greatest feature of "post-apocalyptic" style is the world after eschatology. Whether natural disaster or disaster caused by humans themselves, the whole world is soulless, you can see the "ex" civilization traces everywhere. Such as the flooded Earth in "Water world" , the past hustle and bustle cities now only lying quietly in the seabed, the water floating islands and boats became the new homeland of mankind, only Mount Everest has become a legendary unique land. Another example is the wasteland after the nuclear war in "radiation", the cities already become ruins, dilapidated high buildings has become the home of various mutant animals. The empty cities in "28 Days Later" and "I Am Legend" were just the ruins in another sense.

Ruin is a common element in almost all of the "postapocalyptic" style works. In a destroyed world, is there anything more expressive than ruins and broken walls? A variety of "pre-civilization" remains and ruins as if laughing at the fragile human civilization, and this environment could bring the fear of dark terrible eschatology to the audiences bring viewers to the maximum degree.

\section{B. Element 2: Malformed Future}

Although the background of the "post-apocalyptic" style story all in the future, but the world destruction often occurred in the past or present. It caused a result of: the basis for future technological development is based on the past science and technology, and in this lost civilization world it cannot make normal development, and ultimately developed malformed future world in order to adapt to the environment.

Such as in "radiation" the world was destroyed in a nuclear war during the Cold War, all of the scenes and props with a strong imprint of the 1960s. In such a future world, laser weapons were everywhere, energy armor and nuclear power plants were around the world, intelligent robots and a variety of weird high-technology things running all over the ground. As opposed to this is all of the computers were backward DOS systems, vehicles were only oxcarts, robbers with punk hair and leather jacket dressed like motorbike gangs in 1970s and use Mauser pistols. Such a sharp contrast thus appeared in the same world, but people feel it is perfectly logical and reasonable, which is the most attractive place of "postapocalyptic" style works.

\section{Element 3: Time Imprint}

In the destroyed world, various "Pre-civilization" imprints are essential, that imprints almost directly determined the design style of the entire work. Detailed description with a strong time sense and the sense of substitution, such works evoke memories of the audience and been attracted by it at the same time.

In the various "post-apocalyptic" style works, this time imprint appeared with different manifestations. Costumes, props, scenes, and even music can be used as manifestations, in order to create a style just belong to this era. Such as "Mad 
Max" series, Mel Gibson in the film played a Ranger in the desert world after nuclear war, the film was not only actionpacked, desert filled with sand, isolated small town, motorbike gangs who ride motorbike marauding, all of these provide an excellent model for the future films and all kinds of ACG. Interestingly, "First of the North Star" has a large number of similar settings from the film, the same civilization degraded world after nuclear war, the same hero who wearing a dark blue vest, the same armored soldiers with punk hairstyle. The same material in the hands of different authors produced a very different product. But expressed time spirit are the same. In "radiation" the 1960s posters and appliances can be seen everywhere, large neon signs, jazz master Louis Armstrong's music, abandoned cars by the street, a strong time sense was vividly portrayed.

\section{The Basic Method: Splitting And Reassembly}

The most frequently used method in the "Post-apocalyptic" style work design is the "splitting and reassembly". Everything can be seen as a whole which constituted by a number of elements, the orderly combination between the elements is the structure guarantee to ensure the whole function or the function realization. If you change the order of structural elements of the things on purpose and reassemble them, it may cause the change of function or performance, which is exactly what the innovation and creation need. Thus, after obtaining known materials, in order to create a new world view, we need to split the complete materials apart and then reassembled them in a different way, so that to create refreshing things which also fit the style of the work .

Such as the vehicles in "radiation": two-headed oxcarts, which use car body to replace the ox-cart body. Although only a small change, but expressed the waste land life vividly. Helicopter engine was mounted on the city gate, houses build by the shells of a variety of cars, boats and planes gathered together and formed into village in the atom bomb crater, with the roaring sound of the engine slowly present in front of your eyes.

\section{CONCLUSION}

Since 1964 after "Dr. Strangelove" released, "postapocalyptic" style works formed its own style and standing in the film and game world, particularly eye-catching. This postapocalyptic style is very unique, the films, TV works and games which really belong to the style are not many, the amount is small but they are good quality. The representative works of this style in modern films "The Matrix", "Terminator" and others have also set the trend of science fiction films, in the game field also appeared "radiation", "Wasteland" a series of good works. Today, the "postapocalyptic" style works more and more often appeared in people's visions, through the study of this style, we can observe the trend of world's film, TV work and video game styles and the changes of people's ideology, which has very important meaning for creating outstanding film and television animation works in the future.

\section{REFERENCES}

[1] Liao Xiangzhong. The record of new generation of animation creation. Beijing: China University of Communication Press, 2009

[2] Han Xiao. Scene Design of Television Animation [M]. Beijing: The Ocean Publishing Company, 2005

[3] Han Yu, Yu Fang. Road of Animation: scene design of video animation game [M]. Changchun: Jilin Art Publishing House, 2008 